\title{
Emocionalna inteligencija i agresivno ponašanje u djetinjstvu i adolescenciji - Pregled istraživanja
}

\author{
Ana Babić Čikeš \\ Odsjek za psihologiju, Filozofski fakultet Sveučilišta J.J. Strossmayera u Osijeku, Hrvatska
}

\section{Sažetak}

Svrha je ovog rada dati pregled istraživanja razvoja emocionalne inteligencije (EI) i agresivnosti u djetinjstvu i adolescenciji, kao i studija koje su se bavile odnosom ovih dvaju konstrukata u toj dobi. Već sam pregled podataka o razvoju upućuje na moguće poveznice u razvojnim putanjama emocionalnih sposobnosti i agresivnosti. No istraživanja povezanosti varijabli emocionalnog doživljavanja i procesiranja emocija s različitim aspektima agresivnosti prilično su rijetka. Većina rezultata postojećih istraživanja upućuje na povezanost između ovih dvaju konstrukata, ali problem u donošenju jasnih zaključaka velike su razlike u konceptualizacijama, primijenjenim mjerama, uzorcima i metodama. U budućim je istraživanjima važno usmjeriti se na ispitivanje specifičnih veza između svake razine EI, užih sposobnosti koje pripadaju pojedinim razinama i različitih oblika agresivnosti. Osim toga, važno je ispitati mogućnosti utjecaja na svaku od specifičnih sposobnosti s obzirom na njihove razvojne putanje i važnost za agresivno ponašanje u pojedinoj točki razvoja. Položaj varijabli EI unutar konstelacije mnogih drugih korelata agresivnog ponašanja u različitim razvojnim razdobljima također je bitan problem potencijalnih istraživanja. Primjena bi rezultata takvih istraživanja u kreiranju programa prevencije agresivnog ponašanja povećala njihovu efikasnost, ali i omogućila valjaniju procjenu učinka primijenjenih tretmana.

Ključne riječi: agresivnost, emocionalna inteligencija, djetinjstvo, adolescencija

\section{Uvod}

Agresivnost i različiti oblici nasilja pojave su koje zabrinjavaju mnoge pripadnike suvremenog društva (npr. Horton, 2011; Ružić, 2011). Unatoč činjenici da su takvi oblici ponašanja prisutni tijekom cijeloga razvojnog vijeka ljudske civilizacije, vrijednosti suvremenog društva naglašavaju pravo svakog pojedinca na život, sigurnost i slobodu (Ujedinjeni narodi, 1948; Ustav RH, 2011). To čini kontinuirane napore na prevenciji pojavnosti agresivnih i nasilnih ponašanja smislenima. S obzirom na to da se agresivna ponašanja kod djece javljaju već od 
najranije dobi (Wahl i Metzner, 2012) te se njihova manifestacija mijenja tijekom razvoja (Dodge, Coie i Lynam, 2007), važno je da preventivne aktivnosti sa svrhom njihova smanjivanja budu usmjerene na što raniju dob djece, ali i na različite dobne skupine. Razumijevanje razvojnog puta agresivnosti i njezinih korelata, kao i njihovih međusobnih odnosa mora biti temelj takvih aktivnosti. Agresivno je ponašanje u mnogim slučajevima praćeno intenzivnim emocijama (Hubbard, McAuliffe, Morrow i Romano, 2010; Wahl i Metzner, 2012), stoga bi upravo emocionalne sposobnosti mogle imati važnu ulogu u objašnjenju i prevenciji takvog ponašanja (Bohnert, Crnic i Lim, 2003; Grgić, Babić Č̉ikeš i Ručević, 2014). Pretpostavlja se da osoba više emocionalne inteligencije (EI) svoje emocije koristi na povoljniji način te, posljedično, ima u svom ponašanju i manji broj neprikladnih, pa i agresivnih emocionalnih reakcija. Postoje istraživanja koja su potvrdila povezanost emocionalnih sposobnosti i agresivnog ponašanja (Bohnert i sur., 2003; Liau, Liau, Teoh i Liau, 2003; McLaughlin, Hatzenbuehler, Mennin i NolenHoeksema, 2011; Mohorić, 2012; Munjas, 2007), no u kontekstu modela EI još uvijek ne nalazimo dostatne empirijske nalaze o tijeku razvoja emocionalnih sposobnosti, te mogućnostima unaprjeđivanja tih sposobnosti s ciljem smanjivanja nepoželjnih oblika ponašanja.

Svrha je ovog rada dati pregled istraživanja razvoja EI u djetinjstvu i adolescenciji, kao i pregled studija koje su se bavile odnosom EI i agresivnosti u toj dobi. Da bismo mogli razumjeti vezu između emocionalnih sposobnosti i agresivnog ponašanja, na početku ćemo definirati konstrukt agresivnosti te izložiti podatke o njegovu razvojnom putu i korelatima.

\section{Agresivnost}

Unatoč brojnim i različitim definicijama agresivnog ponašanja (Dodge i sur., 2007; Tremblay, 2000) većina bi se autora složila da je to ponašanje koje ima za cilj povrijediti drugu osobu (Parke i Slaby, 1983), odnosno koje osobe u njezinoj okolini doživljavaju hostilnim (Keresteš, 2006). Iako se ova definicija čini jednostavnom, određivanje što je agresivan čin na temelju nje može biti složeno jer namjere $u$ podlozi ponašanja nisu uvijek dostupne opažanju (TenHouten, 2012). Na primjer, postoje okolnosti u kojima je teško govoriti o namjeri da se povrijedi druga osoba (npr. dijete dojenačke dobi udari drugu osobu prilikom istraživanja okoline svojim tijelom), a ponašanje ima obilježja agresivnog ponašanja (Tremblay, 2000).

Pojam agresivnosti je višeznačan. Pod njim možemo podrazumijevati predispoziciju osobe za ispoljavanje agresivnog ponašanja (TenHouten, 2012; Wahl i Metzner, 2012), pa u tom slučaju na agresivnost gledamo kao na trajnu osobinu ličnosti pojedinca. Osim toga, agresivnost može označavati vrstu emocionalnog stanja u kojem dominira ljutnja (Hubbard i sur., 2010; TenHouten, 2012), jer je agresivan čin često praćen tom emocijom. Neki pod agresivnošću podrazumijevaju i 
stavove prema agresivnom načinu reagiranja (Wahl i Metzner, 2012) očekujući da će se oni koji imaju pozitivne stavove prema agresivnosti (npr. prema tjelesnom kažnjavanju djece) vjerojatnije agresivno i ponašati. U znanstvenim se radovima koji se bave agresivnošću pojmovi agresivnosti i agresivnog ponašanja uglavnom koriste kao međusobno zamjenjivi. Upitnici namijenjeni mjerenju agresivnosti redovito uključuju opise različitih vrsta agresivnog ponašanja čija se učestalost procjenjuje kod sudionika istraživanja (npr. Dennissen, Asendorpf i van Aken, 2008; Smith, Rose i Schwartz-Mette, 2010; Wahl i Metzner, 2012), ali i stavove prema agresivnom ponašanju te emocionalna stanja povezana s agresivnošću (Hubbard i sur., 2010). U ovom nas radu zanimaju podaci o mogućnosti predikcije agresivnog ponašanja na temelju sposobnosti emocionalne inteligencije te ce se pojmovi agresivnosti i agresivnog ponašanja upotrebljavati u smislu zastupljenosti agresivnog ponašanja kod osobe.

Agresivnost je danas prihvaćena kao multidimenzionalni konstrukt čije dimenzije razlikuju različite vrste i funkcije agresivnog ponašanja. Tako agresivno ponašanje može biti direktno (otvoreno) ili indirektno (odnosno). Direktno ili otvoreno agresivno ponašanje usmjereno je izravno na ciljnu osobu te u tom slučaju razlikujemo tjelesnu od verbalne agresije (Smith i sur., 2010; Xie, Drabick i Chen, 2011). Takvo je ponašanje ono što se uobičajeno smatra pod pojmom agresivnosti i lakše ga je identificirati od indirektne ili odnosne agresivnosti. Indirektna agresivnost uključuje one oblike ponašanja koji imaju za cilj nanijeti štetu drugoj osobi, ali ne putem izravne interakcije s ciljnom osobom, nego ponašanjima poput širenja glasina, ogovaranja, isključivanja i sl. (Crick i sur., 1999). Istraživanja pokazuju da su ove dvije vrste agresivnosti povezane na razini $r=.60-.76$ (Card, Stucky, Sawalani i Little, 2008; Crick i sur., 1999), što znači da mnoga djeca pokazuju obje vrste agresivnog ponašanja, no neka se dominantno ponašaju na jedan od opisanih načina (Smith i sur., 2010). Direktna je agresija povezana više s eksternalizirajućim ponašanjima, lošim socijalnim odnosima i manjom učestalosti prosocijalnog ponašanja, a indirektna s internalizirajućim problemima i češćim prosocijalnim ponašanjem (Card i sur., 2008). Druga dimenzija ovog konstrukta razlikuje agresivna ponašanja $s$ obzirom na to koju funkciju ona imaju za osobu koja ih iskazuje. Prema toj dimenziji agresivnost dijelimo na proaktivnu i reaktivnu (Hubbard i sur., 2010). Proaktivna agresija je na neki način "svjesna" i "planirana", odnosno namijenjena tome da osoba ostvari neki svoj cilj agresivnim ponašanjem. Reaktivna je agresija u većoj mjeri vođena slabo kontroliranim negativnim osjećajima osobe i predstavlja odgovor na stvarnu ili zamišljenu provokaciju. Istraživanja pokazuju da je proaktivna agresija povezana $s$ delinkventnim ponašanjem i psihopatijom, a reaktivna s nasiljem $u$ bliskim vezama (vidi Hubbard i sur., 2010). Razlikovanje navedenih formi agresivnog ponašanja važno je zbog razlika u obrascima veza s konstruktima koji mogu biti povezani s učestalošću ili težinom njihova javljanja, ali i njihovim razvojnim putanjama (npr. Hubbard i sur., 2010; Ojanen, Findley i Fuller, 2012; Xie i sur., 2011). 
$\mathrm{U}$ istraživanjima se agresivnog ponašanja koriste različite vrste mjera, od procjena drugih ljudi, preko samoprocjena do opažanja u laboratorijskim ili prirodnim uvjetima. U svrhu se procjene zastupljenosti agresivnog ponašanja kod djece uglavnom primjenjuju procjene roditelja odnosno skrbnika, odgajatelja ili učitelja (Keresteš, 2006; Xie i sur., 2011). Kod starije se djece i adolescenata, osim procjena odraslih, često upotrebljavaju procjene vršnjaka (Gleason, JensenCampbell i Richardson, 2004; Keresteš, 2006; Ojanen i sur., 2012) te samoprocjene (npr. Batool, 2013; Brame, Nagin i Tremblay, 2001; Little, Jones, Henrich i Hawley, 2003; Wahl i Metzner, 2012). Opažanje se, vjerojatno zbog zahtjevnosti te metode, rabi najrjeđe (Hubbard i sur., 2010). Svaka od ovih vrsta mjera ima svoje poznate prednosti i nedostatke, a s obzirom na to da se njima zahvaća predmet mjerenja $u$ različitim kontekstima, odnosno s različitih gledišta, očekivani su i različiti, ali međusobno korelirani rezultati prikupljeni različitim vrstama mjera $u$ isto vrijeme na istom uzorku (Keresteš, 2006). Podaci prikupljeni u istom kontekstu više međusobno koreliraju, kao i procjene onih opažača koji raspolažu sličnijim informacijama o ponašanju osobe (Keresteš, 2006; Wahl i Metzner, 2012). S obzirom na to očekuje se da veličine povezanosti agresivnosti s nekim drugim konstruktima također $\mathrm{u}$ određenoj mjeri ovise o vrsti primijenjenih mjera.

\section{Razvoj i korelati agresivnosti}

Djeca počinju ispoljavati agresivno ponašanje kad za to postanu tjelesno sposobna, otprilike u dobi od godinu dana (Alink i sur., 2006; Tremblay i sur., 1999). Tijekom idućih nekoliko godina ona pokazuju uglavnom izravne, najčešće fizičke, oblike agresivnih ponašanja i to zahvaljujući još nedovoljno razvijenom govoru i ograničenjima kognitivnoga, socijalnoga, moralnoga i emocionalnoga razvoja. Istraživanja pokazuju da je kulminacija fizičke agresivnosti tijekom ranog djetinjstva negdje između dvije i četiri godine (Alink i sur., 2006; Tremblay i sur., 1999), a nakon tog razdoblja dolazi do opadanja. Praćenja zastupljenosti tjelesno agresivnih ponašanja od ranog djetinjstva sve do kasne adolescencije upućuju na kontinuirani pad. Samo je mali postotak i dječaka i djevojčica (ispod 10\%) fizički kontinuirano agresivno tijekom srednjeg djetinjstva i adolescencije (Tremblay i sur., 1999).

Istraživanja su verbalne agresivnosti puno rjeđa, a često se u studijama ne izdvaja verbalna od ukupne ili otvorene agresivnosti. Zbog toga ne raspolažemo s dovoljno empirijskih informacija o razvoju verbalne agresivnosti. No, poznato je da zastupljenost verbalno agresivnih ponašanja $u$ repertoaru ponašanja djeteta raste sukladno s razvojem govora (Tremblay i sur., 1999). Što se tiče školske dobi, neka istraživanja pokazuju da se verbalna agresivnost od školske dobi nadalje javlja češće (Hartup, 1974; McCabe i Lopscomb, 1988), dok druga istraživanja pokazuju da verbalna agresivnost, kao i fizička, opada tijekom osnovne škole (Choie i Dodge, 1997; Parke i Slaby, 1983). 
S odrastanjem i stjecanjem verbalnih i socijalnih vještina sve se češće javljaju različiti oblici indirektne agresivnosti (Crick i sur., 1999; Smith i sur., 2010). Već se u dobi od tri do pet godina mogu uočiti jednostavniji oblici takvih ponašanja kod djece (Cakić i Velki, 2014; Crick, Casas i Mosher, 1997), a s dobi indirektno agresivna ponašanja postaju sve složenija i sofisticiranija (Crick i sur., 1999). Istraživanje koje su proveli Cairns, Cairns, Neckerman, Ferguson i Gariépy (1989) pokazalo je porast indirektne agresivnosti $u$ ranoj adolescenciji, a istraživanje na uzorku hrvatskih učenika potvrdilo je da učenici 8. razreda osnovne škole pokazuju više indirektno nasilnih ponašanja od učenika 4. razreda (Đuranović i Opić, 2013). $\mathrm{Na}$ istraživanja razvoja indirektne agresivnosti u kasnijim razvojnim periodima nismo naišli. Istraživanje samoprocijenjene agresivnosti koje su Dutt, Pandey, Pal, Hazra i Dey (2013) proveli na učenicima rane adolescentne dobi pokazalo je da je u toj dobi najzastupljenija tjelesna agresivnost, zatim verbalna, a najmanje indirektna agresivnost.

Razvojne su studije agresivnosti također usmjerene na interindividualne razlike u početku javljanja agresivnosti i daljnjem tijeku njezina razvoja. Xie i sur. (2011) proveli su longitudinalno istraživanje otvorene agresivnosti (tjelesne i verbalne) na sudionicima obaju spolova od 4. do 12. razreda. Prema početku javljanja i razvojnim putanjama otvorene agresivnosti identificirali su četiri skupine sudionika: niska, rastuća (početak u adolescenciji), opadajuća i visoka (početak u djetinjstvu). Većina mladih pripada skupini nisko agresivnih, dok je mali postotak visoko agresivno. Skupine se razlikuju i po zastupljenosti rizičnih faktora u različitim razdobljima života. Visoko agresivni imaju više rizičnih faktora u djetinjstvu od rastuće agresivnih, kod kojih je pak zapažena visoka razina neovisnosti u adolescenciji. S druge strane, opadajući su izloženi nekim rizičnim faktorima u djetinjstvu, ali je kod njih $u$ adolescenciji uočena visoka razina roditeljskog nadgledanja i uključenosti škole. Govoreći o razvojnim putanjama tjelesne agresivnosti, Brame i sur. (2001), prema nalazima svog istraživanja, zaključuju da je prijelaz iz niske agresivnosti $u$ djetinjstvu u visoku agresivnost $u$ adolescenciji malo vjerojatan. Oni koji pokazuju agresivno ponašanje $u$ adolescenciji uglavnom su agresivni od djetinjstva (Alink i sur., 2006; Brame i sur., 2001; Kokko, Pulkkinen, Huesmann, Dubow i Boxer, 2009). Istraživanja spolnih razlika pokazuju da su djevojčice koje učestalo ispoljavaju agresivno ponašanje s dobi sve manje fizički agresivne, dok kod dječaka rezultati nisu jednoznačni. Rezultati nekih studija pokazuju da učestalost fizičke agresivnosti kod agresivnih dječaka opada (Bongers, Koot, van der Ende i Verhulst, 2003; Wahl i Metzner, 2012), a drugih da ostaje stabilna (Lee, Baillargeon, Vermunt, Wu i Tremblay, 2007).

Što se tiče korelata agresivnosti kod djece i adolescenata, jedan od najčešće istraživanih je spol. Istraživanja potvrđuju da su dječaci u svim razdobljima odrastanja tjelesno agresivniji od djevojčica, dok rezultati istraživanja spolnih razlika u verbalnoj agresiji i indirektnim oblicima agresivnosti nisu konzistentni (Batool, 2013; Card i sur., 2008; Dutt i sur., 2013; Đuranović i Opić, 2013; Parke i Slaby, 
1983; Smith i sur., 2010; Tapper i Boulton, 2004; Xie i sur., 2011). Od bioloških se korelata agresivnosti još spominje genetska predispozicija (Pérusse i Gendreau, 2005) te neke značajke temperamenta. Na primjer, u istraživanju se Ojanena i sur. (2012) pokazalo da je razina frustracije kod osobe negativno povezana s indirektnom agresivnošću ranih adolescenata, ali nije povezana s otvorenom agresivnošću. I druge su karakteristike djeteta, kao što su osobine ličnosti i načini procesiranja informacija, također povezane $\mathrm{s}$ agresivnim ponašanjem. Ugodnost i savjesnost negativno su povezane s direktnim i indirektnim agresivnim ponašanjem ranih adolescenata obaju spolova (Gleason i sur., 2004), a narcizam je pozitivno povezan s tjelesnom agresijom dječaka i indirektnom agresijom obaju spolova (Ojanen i sur., 2012).

$\mathrm{Na}$ važnost učenja i socio-kognitivnih varijabli u tumačenju agresivnog ponašanja upozorio je Bandura (Bandura, 1973; Bandura, Ross i Ross, 1961). Istraživanja su potvrdila da je zastupljenost različitih agresivnih reakcija povezana s načinima na koje atribuiramo socijalne znakove, stavovima prema agresivnosti, namjerama $u$ podlozi ponašanja, dostupnošću naučenih agresivnih reakcija $u$ repertoaru ponašanja i sl. (vidi Hubbard i sur., 2010; Ojanen i sur., 2012). Pojedinci koji češće pokazuju reaktivno agresivna ponašanja skloniji su, u usporedbi $\mathrm{s}$ proaktivno agresivnima, neutralnim ili nejasnim socijalnim znakovima atribuirati neprijateljstvo, a imaju i više poteškoća općenito u razumijevanju socijalnih znakova. Osim toga, pokazalo se da reaktivno agresivna djeca raspolažu i s manje neagresivnih odgovora u svom repertoaru ponašanja. $\mathrm{S}$ druge strane, proaktivno agresivni pojedinci imaju viša očekivanja o tome da će agresivni postupak rezultirati za njih pozitivnim ishodom i osjećaju veću samoefikasnost vezano za agresivna ponašanja koja pokazuju. Istraživanja povezanosti agresivnosti s varijablama emocionalnog doživljavanja i procesiranja emocija prilično su rijetka unatoč emocionalnoj podlozi agresivnog ponašanja. Pregled ćemo tih istraživanja dati u posljednjem dijelu ovog rada.

Veliku se važnost $\mathrm{u}$ etiologiji agresivnosti daje okolinskim faktorima, najčešće različitim obiteljskim varijablama, kao što su stil privrženosti roditelja i djeteta, roditeljski stil, ponašanje roditelja, obiteljska klima i sl. Istraživanja su pokazala da su izbjegavajuća i dezorganizirana privrženost povezane $\mathrm{s}$ više agresivnog ponašanja, kao i manjak topline $u$ odnosu roditelja i djece te suviše nasilnih postupaka discipliniranja djece (Pei, 2011; Wahl i Metzner, 2012). Autoritativni je roditeljski stil negativno povezan s tjelesnom i verbalnom agresivnošću djece, dok je permisivni stil pozitivno povezan s tjelesnom, a autoritarni s verbalnom agresivnošću djece (Batool, 2013). Ipak, važno je naglasiti da su spol roditelja i djeteta medijatori veze između roditeljskih postupaka i dječje agresivnosti, odnosno da isto majčino i očevo ponašanje ima različite efekte za djevojčice odnosno dječake (Björkqvist i Österman, 1992; Pei, 2011; Wahl i Metzner, 2012). Pei (2011) navodi da majčino ponašanje ima više utjecaja na agresivnost djevojaka, a očevo na agresivnost mladića, dok Wahl i Metzner (2012) zaključuju da majčine varijable imaju snažnije efekte od očevih na agresivnost djece. Detaljniji bi pregled istraživanja na tu temu, $\mathrm{s}$ 
obzirom na heterogenost dobivenih rezultata, bio preopširan za ovaj rad. Osim obiteljskih varijabli, značajnim korelatima agresivnog ponašanja pokazali su se i socioekonomski i kulturalni okoliš (Barker i sur., 2008; Damar, Gülay i Seven, 2011). U istraživanju koje su proveli Wahl i Metznerova (2012) dobiveno je da je nizak prihod obitelji povezan s agresivnošću djevojaka.

Pregled razvojnih istraživanja agresivnosti sugerira mnoge probleme. Najuočljiviji su problemi definicije, konceptualizacije i operacionalizacije agresivnosti, koji se razlikuju od studije do studije i time otežavaju sumiranje dobivenih rezultata. Nadalje, najčešće su metode procjene agresivnosti procjene roditelja, vršnjaka ili drugih bliskih osoba te samoprocjene. Ti načini prikupljanja podataka ovdje, kao i u mjerenju drugih konstrukata, u određenoj mjeri iskrivljuju rezultate. Neki od razloga su (ne)znanje procjenjivača o ispitivanom fenomenu (npr. agresivnosti), dostupnost informacija o ispitivanom ponašanju (npr. koliko često ciljna osoba pokazuje agresivna ponašanja), mogućnost procjene ponašanja na određenoj skali (npr. na Likertovoj skali od 5 stupnjeva), kriterij koji svaka pojedina osoba primjenjuje u procjeni (blaži nasuprot strožem), socijalna poželjnost odgovora (pitanje umanjivanja ili naglašavanja pojedinih ponašanja) itd. Pregled sadržaja istraživanja otkriva da najviše znamo o fizičkoj agresiji, dok su drugi oblici agresivnosti, osobito indirektni, zanemareni. Osim toga, najviše je istraživanja na učenicima osnovne škole, dok su rijetka istraživanja mlađe djece i starijih adolescenata. Longitudinalna istraživanja koja bi obuhvatila različite vrste agresivnosti i dulji razvojni period te omogućila opisivanje razvoja i njegovih korelata bila bi od velike koristi u proučavanju razvoja agresivnosti.

\section{Razvoj sposobnosti emocionalne inteligencije}

Prema autorima konstrukta emocionalne inteligencije (EI), Johnu Mayeru i Peteru Saloveyu (1997), EI uključuje sposobnosti točnog prepoznavanja i izražavanja emocija, sposobnosti razumijevanja i generiranja osjećaja koji olakšavaju mišljenje, sposobnosti razumijevanja emocija i znanje o emocijama te sposobnosti reguliranja emocija. Navedene su sposobnosti prikazane na dijagramu s četiri razine i poredane su od jednostavnijih psiholoških procesa (prepoznavanje emocija) prema višim, psihološki objedinjenim procesima (upravljanje svojim i tuđim emocijama). Svaka razina ima četiri reprezentativne sposobnosti pri čemu su sposobnosti koje se javljaju na razmjerno ranom stupnju razvoja smještene na lijevoj strani dijagrama (npr. sposobnost zapažanja emocija u nečijem tjelesnom stanju osjećajima i mišljenju), a one koje se razvijaju kasnije, na desnoj (npr. sposobnost razlikovanja točnog od netočnog, odnosno iskrenog od lažnog izražavanja emocija). Od ljudi visoke EI očekuje se da brže i u većem broju savladavaju spomenute sposobnosti. U nastavku slijedi pregled istraživanja njihova razvoja. 


\section{Razvoj sposobnosti prepoznavanja emocija}

Sposobnosti točne percepcije i procjene emocionalnog sadržaja, kao i ekspresije doživljenih emocija smatraju se temeljnim sposobnostima EI. Mayer i Salovey (1997) smatraju da ova razina uključuje sposobnost zapažanja emocija u jeziku i ponašanju drugih ljudi, te u umjetničkim djelima, sposobnost točnog izražavanja emocija i potreba povezanih s tim emocijama, kao i sposobnost razlikovanja točnih od netočnih, odnosno iskrenih od lažnih izraza emocija. Istraživanja pokazuju da dojenčad već u dobi od tri ili četiri mjeseca može razlikovati neke facijalne i vokalne ekspresije emocija, a u dobi od godinu dana rabe svoja zapažanja emocionalnih ekspresija kao vodiče za ponašanje u nesigurnim situacijama (vidi u Grossman, 2010). Značajan se napredak ovih sposobnosti bilježi u dobi od dvije do četiri i pol godine (Denham i Couchoud, 1990; Wang, Liu i Su, 2014), a nastavlja se i nakon tog perioda sve do razdoblja adolescencije (Herba, Landau, Russell, Ecker i Phillips, 2006). Općenito se pozitivne emocije u usporedbi s negativnim prepoznaju ranije i točnije (Wang i sur., 2014), kao i primarne emocije u usporedbi sa složenim (Boyatzis, Chazan i Ting, 1993; Camras i Allison, 1985; Widen i Russell, 2008). Istraživanja također pokazuju da se ekspresije sreće i tuge mogu točno kategorizirati ranije nego ekspresije straha i gađenja, dok za ljutnju rezultati nisu jednoznačni (Boyatzis i sur., 1993; Camras i Allison, 1985; Gosselin, 1995). Procjena dobi u kojoj djeca prepoznaju emocije jednako kao i odrasli ovisi o tome što se od njih u nekoj situaciji traži. Bruce i sur. (2000) su pokazali da šestogodišnjaci mogu točno pokazati koje je od dva prezentirana lica sretno, tužno, ljuto ili iznenađeno, dok tek desetogodišnjaci mogu između dva lica izabrati ono koje izražava istu emociju kao neko treće lice. Durand, Gallay, Seigneuric, Robichon i Baudouin (2007) smatraju da se ove sposobnosti u potpunosti razviju tek oko desete godine, no Herba i sur. (2006) su u svom istraživanju utvrdili određeni napredak sve do razdoblja srednje adolescencije.

Paralelno s prepoznavanjem tuđih emocija, a vrlo intenzivno $\mathrm{u}$ dobi između 12 i 28 mjeseci (Saarni, 2000), razvija se i svjesnost o vlastitim emocijama. Dijete je već u dobi između dvije i pol i pet godina sposobno komunicirati o svojim emocijama i događajima koji ih izazivaju. Do adolescencije djeca postaju svjesna vlastitih emocionalnih ciklusa (npr. sram zbog osjećaja straha), a u ranoj adolescenciji mješovitih, katkad i suprotnih osjećaja prema istoj osobi. U pubertetu dolazi do rasta svjesnosti o socijalnim osjećajima (sram, krivnja), pa i o mješavinama tih osjećaja (Burnett, Thompson, Bird i Blakemore, 2010).

Razumijevanje prikrivenih osjećaja i upotreba strategija pokazivanja osjećaja također se javlja u predškolskoj dobi (Field i Walden, 1982; Lewis, Sullivan i Vasen, 1987; Malatesta, Culver, Tesman i Shepard, 1989), a najveći skok u tim sposobnostima događa se tijekom osnovne škole (Denham, 1998). Mlađa djeca (5 6 godina) disimulaciju emocija tumače kao promjenu u doživljenim emocijama, dok 
starija djeca (9 - 10 godina) znaju objasniti uzroke tog fenomena (Perron i sur., 2009).

\section{Razvoj sposobnosti upotrebe emocija}

Druga razina modela obuhvaća sposobnosti koje se tiču direktnog utjecaja emocija na procese mišljenja (Mayer i Salovey, 1997). Mnogo je istraživanja potvrdilo postojanje veza između različitih aspekata emocionalnih stanja i kognicije (npr. Beer, Knight i D'Esposito, 2006; Johnson, Waugh i Fredrickson, 2010; Levine i Edelstein, 2009; Mathersul i sur., 2009; Storbeck i Clore, 2007). Johnson i sur. (2010) su našli da poticanje pozitivnih emocija kod sudionika istraživanja proširuje pažnju prilikom rješavanja zadatka vizualnog procesiranja, a Levine i Edelstein (2009) su pregledom istraživanja potvrdili da emocije olakšavaju pamćenje informacija povezanih s aktualnim ciljevima osobe. Mathersul i sur. (2009) su na velikom uzorku od 1000 osoba dobi od 9 do 61 godine dokazali pozitivnu povezanost između varijabli prepoznavanja emocija i varijabli općega kognitivnog funkcioniranja.

Unatoč istraživanjima koja potvrđuju pozitivnu ulogu emocija u kognitivnom funkcioniranju osoba ova se razina EI (sposobnosti upotrebe emocija kao olakšica mišljenju) vrlo često zaobilazi u istraživanjima. Jedan bi od razloga mogao biti teškoće $u$ operacionalizaciji ove sposobnosti, na što upućuje i činjenica da $u$ empirijskim radovima nalazimo samo jedan instrument namijenjen njezinu mjerenju i to u sklopu testa MSCEIT (Mayer, Salovey, Caruso i Sitarenios, 2003). Sposobnosti upotrebe emocija konceptualizirane su po prvi put u ovom modelu EI i prije nisu bile predmetom istraživanja. Drugi bi razlog mogao biti taj što se ova razina pokazala problematičnom $\mathrm{u}$ istraživanjima faktorske strukture MSCEIT-a. Metaanaliza provedena metodom strukturalnog modeliranja nad podacima iz 19 istraživanja na ukupno 10573 sudionika pokazala je da podacima najbolje pristaje trofaktorska struktura, u kojoj prva i druga razina modela Mayera i Saloveya (1997) čine jedan faktor (Fan, Jackson, Yang, Tang i Zhang, 2010). S obzirom na prethodno rečeno nemamo podataka o razvoju sposobnosti upotrebe emocija u facilitaciji mišljenja.

\section{Razvoj sposobnosti razumijevanja emocija}

S razvojem kognitivnih i jezičnih sposobnosti razvijaju se i sposobnosti razumijevanja svojih i tuđih osjećaja. One uključuju imenovanje emocija i razumijevanja odnosa između riječi i emocija, razumijevanje uzroka emocija, mješavina emocija te vjerojatnih prijelaza između emocija.

S otprilike tri godine djeca počinju konceptualizirati i imenovati različite emocije, a ta se sposobnost dalje razvija tijekom predškolskog perioda (Ridgeway, Waters i Kuczaj, 1985; Wang i sur., 2014). Ekspresije tuge i sreće imenuju se ranije od ekspresija ljutnje ili straha (Denham, 1998), a još se kasnije javljaju izrazi za 
složene emocije. Istraživanja su pokazala da djeca u početku stvaraju dvije široke kategorije osjećaja koje se mogu nazvati pozitivnom i negativnom, a zatim se te kategorije diferenciraju u uže kategorije koje su sve sličnije onima kojima se koriste odrasli (Widen i Russell, 2008).

U predškolskoj se dobi poboljšava i razumijevanje uzroka emocija $u$ emocionalnim situacijama (Ashiabi, 2000). Djeca u dobi od četiri ili pet godina pokazuju razumijevanje različitih uzroka roditeljske sreće, tuge ili ljutnje (Denham, 1998), dok trogodišnjaci još imaju teškoća u tome. Istraživanje u kojima se od predškolaca tražilo da popune priče o tome zašto se protagonist osjeća na određeni način i što je kao rezultat toga učinio, pokazalo je da oni mogu razlikovati uzroke emocija od njihovih posljedica (Russell, 1990), te da imaju prilično točne ideje o ponašajnim posljedicama emocija.

Djeca u dobi od sedam godina shvaćaju da dvije emocije istog predznaka mogu biti usmjerene prema istom objektu, a do dobi od 11 godina spoznaju da se i osjećaji suprotnog predznaka mogu izraziti prema istom objektu (Denham, 1998).

Najkompleksnija je sposobnost ove razine razumijevanje slijeda emocija (Mayer i Salovey, 1997), ali nismo naišli na istraživanja koja se bave njezinim razvojem.

\section{Razvoj sposobnosti upravljanja emocija}

Na najvišoj se razini modela nalaze sposobnosti emocionalne regulacije, kao najkompleksnije sposobnosti emocionalne inteligencije (Mayer i Salovey, 1997). Mayer i Salovey pretpostavljaju da osobe koje su u stanju otvoriti se osjećajima, razumjeti ih, odvojiti se od njih ili uroniti u njih kad je potrebno, mogu iskoristiti te osjećaje za vlastitu dobrobit i dobrobit ljudi oko sebe, bez obzira kojeg predznaka ili intenziteta oni bili. Preduvjeti su razvoja sposobnosti upravljanja emocijama ranije opisane sposobnosti nižih razina.

U ranom je djetinjstvu i predškolskoj dobi često potrebna podrška odraslih u regulaciji emocija, a s vremenom dijete postaje sve sposobnije u korištenju vlastitih strategija. Posebnu važnost za samoregulaciju kod djece ima jezik emocija jer omogućuje razumijevanje vlastitih osjećaja te procesiranje uzročnih veza između događaja i emocija omogućavajući izbor odgovora suočavanja (Kopp, 1989). Tijekom druge i treće godine djeca počinju upotrebljavati jezik i da bi utjecali na odrasle i time zadovoljili vlastite emocionalne potrebe (Dunn, Brown i Beardsall, 1991).

Tijekom odrastanja se struktura samoregulacijskih strategija mijenja. U dojenačkoj se dobi zapaža upotreba samoregulatornih (npr. orijentacija prema ili od podražaja, samodistrakcija putem fizičkog samotješenja i samostimulacije) i heteroregulatornih strategija (protestiranje, plakanje, privlačenje pažnje odraslih pogledom ili osmjehom). Samoregulatorne strategije se prema kraju prve godine života koriste sve rjeđe, dok heteroregulatorne postaju sve učestalije (Bridges i 
Grolnick, 1995). U drugoj godini života djeca koriste fizičko samotješenje, heteroregulatorne strategije i distrakcije putem orijentacije prema okolini (Grolnick, Bridges i Connell, 1996; Mangelsdorf, Shapiro i Marzolf, 1995), a te strategije krajem druge godine, kada se javlja simboličko mišljenje, postaju sve kompleksnije. Tada se djeca u svrhu regulacije osjećaja počinju koristiti prijelaznim objektima, simboličkom igrom odnosno samogovorom (Feldman, 2007). Nakon razdoblja ranog djetinjstva smanjuje se učestalost ponašajnih problema (npr. ispadi bijesa) koji su rezultat snažnog negativnog afekta, a to se vjerojatno događa zbog porasta repertoara emocionalnih, kognitivnih i bihevioralnih strategija suočavanja koje su relevantne za određenu situaciju (Cole, Michel i Teti, 1994).

Pretpostavlja se da je razvoj strategija regulacije u potpunosti završen tek u kasnom djetinjstvu ili adolescenciji (Bronson, 2000; Demetriou, 2000), ali rezultati se istraživanja razlikuju ovisno o tome koje se strategije ispituju i na kojim dobnim skupinama. Rezultati studije koje su proveli Raffaeli, Crockett i Shen (2005) upućuju na porast opće razine samoregulacije od ranog do srednjeg djetinjstva i odsustvo promjene od srednjeg djetinjstva do rane adolescencije. Longitudinalna je studija koju su proveli Murphy, Eisenberg, Fabes, Shepard i Guthrie (1999) pokazala da je primjena strategija promjene pažnje $\mathrm{i}$ inhibitorne kontrole $\mathrm{u}$ razdoblju od srednjeg djetinjstva do adolescencije $u$ porastu, dok je impulzivnost u opadanju. $\mathrm{S}$ druge strane, čestina primjene strategija fokusiranja pažnje i regulacije ponašanja ostaje stabilna. Jaffe, Gullone i Hughes (2010) našli su da na prijelazu iz kasnog djetinjstva u ranu adolesceniju dolazi do češće upotrebe strategije ponovne procjene dok nema promjena u upotrebi strategije potiskivanja ekspresije osjećaja. Ponovna se procjena, kao kognitivna strategija, unatoč porastu, $\mathrm{u}$ adolescenciji još uvijek rjeđe koristi $\mathrm{u}$ odnosu na odraslu dob (McRae i sur., 2012). Istraživanja upravljanja emocijama tijekom adolescencije također daju različite rezultate. Silkova, Steinberg i Morrisova (2003) nisu potvrdili promjene u strategijama regulacije emocija od rane do srednje adolescencije, dok neka druga istraživanja upućuju na učestaliju upotrebu tih strategija u srednjoj adolesceniji (Gullone, Hughes, King i Tonge, 2010; Zeman i Shipman, 1997). Zimmermann i Iwanskova (2014) su našli da adolescenti u srednjoj adolescenciji raspolažu s najmanjim brojem strategija regulacije. No, njihovi rezultati upućuju na značajne promjene tijekom adolescencije i odrasle dobi. Adaptivna se regulacija emocija i traženje socijalne podrške mijenjaju tijekom adolescencije prema U-krivulji, pasivnost opada nakon rane adolescencije, a izbjegavanje se koristi rijetko, no podjednako često tijekom adolescencije i odrasle dobi. Uspoređujući s ranom odraslom dobi, supresija osjećaja i opća disregulacija se u ranoj i srednjoj adolescenciji koriste rjeđe, a disfunkcionalna ruminacija u ranoj adolescenciji češće. Ovo je istraživanje pokazalo i da se upotreba ovih strategija razlikuje s obzirom na kvalitetu doživljene emocije. Npr. tuga se u usporedbi sa strahom i ljutnjom češće regulira traženjem socijalne podrške, pasivnošću i izbjegavanjem, a za upravljanje strahom se češće koriste potiskivanje osjećaja i ruminacija. Disregulacija i disfunkcionalna ruminacija češće se upotrebljavaju u regulaciji ljutnje u usporedbi s tugom. 
Sva ova istraživanja sugeriraju da s dobi djeca postupno stječu nove strategije upravljanja osjećajima i da su u različitim razvojnim razdobljima sklonija koristiti neke od tih strategija. Osim toga, upotreba strategija varira od situacije do situacije. U kontekstu agresivnosti bilo bi važno znati na koji način djeca u određenim razdobljima upravljaju emocijama koje dovode do agresivnih ponašanja te koje su strategije učinkovitije u prevenciji pojave takvih ponašanja.

\section{Osvrt na istraživanja razvoja emocionalnih sposobnosti}

Pregled rezultata o razvoju emocionalnih sposobnosti sugerira da se istraživanja uglavnom ne temelje na konceptualizacijama EI, nego proizlaze iz razvojnih istraživanja u okviru drugih teorija i modela. Raznovrsnost teorijskih i metodoloških pristupa, primijenjenih mjera i razina analize značajan su problem u objedinjavanju podataka tih studija (Sheffield Morris, Silk, Steinberg, Myers i Robinson, 2007). Moguće razloge za manjak istraživanja razvoja EI vidimo u tome što se autori koji se bave ovim konstruktom uglavnom bave individualnim razlikama u sposobnostima i crtama ličnosti, a manje razvojem. Osim toga, razvojna su istraživanja metodološki i financijski vrlo zahtjevna, a jedan je od problema u istraživanjima EI i problem mjerenja (npr. Petrides, Furnham i Mavroveli, 2007; Roberts, Zeidner i Matthews, 2001; Takšić, Mohorić i Munjas, 2006), što otežava metodološki aspekt ionako izazovnih studija razvoja EI. Nadalje, model Mayera i Saloveya (1997) vrlo je kompleksan i većina istraživanja uključuje samo neke varijable proizašle iz modela. Kao što je već objašnjeno na kraju poglavlja vezanog uz razvoj sposobnosti upotrebe emocija, sustavno je zanemarena druga razina modela, što bi moglo upućivati na potrebu revidiranja modela.

Podaci o razvoju emocionalnih sposobnosti uglavnom se tiču razvoja u ranom djetinjstvu, odnosno predškolskoj dobi, dok je manje dostupnih podataka o razvoju u srednjem djetinjstvu i adolescenciji (Zimmerman i Iwanski, 2014). Najnovija istraživanja emocionalnog razvoja ističu i važnost detektiranja obrazaca specifičnih za vrstu doživljene emocije (Zimmerman i Iwanski, 2014), kao i njezin intenzitet (Herba i sur., 2006), no takvih je istraživanja još uvijek vrlo malo.

Sve navedeno upućuje na zaključak da ima još mnogo prostora za istraživanja razvoja emocionalnih sposobnosti, osobito u razdobljima srednjeg djetinjstva i adolescencije, koja su iznimno važna jer se većina programa za razvoj emocionalne inteligencije provodi upravo kod populacije školske djece. Logično je pretpostaviti da bi primjena rezultata takvih istraživanja u kreiranju preventivnih programa povećala njihovu efikasnost, ali omogućila i valjaniju procjenu učinka primijenjenih tretmana. No da bi došlo do potrebnog napretka, nužno je riješiti navedene konceptualne i metodološke probleme. 


\section{Emocionalna inteligencija i agresivnost}

Već sam pregled podataka o razvoju emocionalnih sposobnosti i agresivnosti upućuje na moguće poveznice u njihovim razvojnim putanjama. U općoj je populaciji djece tjelesno agresivno ponašanje najučestalije u dobi od dvije do četiri godine (Alink i sur., 2006; Tremblay i sur., 1999), a to je i razdoblje u kojem djeca tek počinju svjesno prepoznavati svoje i tuđe osjećaje, imenovati ih i razumijevati njihove uzroke (Ashiabi, 2000; Denham i Couchoud, 1990; Ridgeway i sur., 1985; Wang i sur., 2014). Sposobnosti prepoznavanja i razumijevanja emocija prvo se razvijaju za emociju sreće, zatim tuge, a kasnije za emocije straha i ljutnje (Boyatzis i sur., 1993; Camras i Allison, 1985; Denham, 1998; Gosselin, 1995). Očekivano je stoga da ograničenja u sposobnostima povezanima s emocijama ljutnje ograničavaju i mogućnost kontrole agresivnosti. U dobi od četiri ili pet godina kod djece se uočava napredak sposobnosti razumijevanja uzroka emocija (Denham, 1998), a to je upravo i razdoblje u kojem se događa pad učestalosti agresivnih ponašanja. Sposobnost razumijevanja složenih, socijalnih i mješavina osjećaja dalje se razvija kroz srednje djetinjstvo i adolescenciju (Burnett i sur., 2010; Denham, 1998), što možemo povezati s daljnjim smanjenjem agresivnog ponašanja kod djece, osobito djevojčica (Alink i sur., 2006; Tremblay i sur., 1999). Manja učestalost agresivnih ponašanja kod djevojčica u skladu je s nalazima o prednosti žena u emocionalnim sposobnostima (npr. Austin, 2005; McIntyre, 2010; Williams, Daley, Burnside i Hammond-Rowley, 2010). Nadalje, tijekom osnovne škole događa se najveći napredak u strategijama pokazivanja osjećaja (Denham, 1998), što također može biti u vezi s agresivnošću, osobito indirektnom. Osim sa sposobnostima prepoznavanja i razumijevanja osjećaja, agresivnost je očekivano povezana i sa sposobnostima upravljanja emocijama. U prvih se nekoliko godina života repertoar strategija regulacije emocija drastično mijenja i povećava (Feldman, 2007; Grolnick i sur., 1996; Mangelsdorf i sur., 1995), reflektirajući se i na agresivno ponašanje djece. Razvoj tih strategija traje sve do adolescencije (Jaffe i sur., 2010; Murphy i sur., 1999; Raffaeli i sur., 2005), a i kasnije se uočavaju određene promjene u čestini njihove upotrebe (McRae i sur., 2012). Kako se očekuje da razvoj u toj dobi slijedi putanju napretka, pretpostavljamo da napredak u emocionalnoj regulaciji omogućuje sve veću kontrolu emocija, pa i emocija ljutnje.

U nastavku ćemo navesti rezultate istraživanja povezanosti EI i agresivnosti, a važno je naglasiti da smo izdvojili ona koja su koristila neku od mjera agresivnosti u užem smislu (kako smo definirali u poglavlju o agresivnosti), te nismo uključili istraživanja koja istražuju veze s različitim oblicima drugih devijantnih ponašanja. Smatrali smo da je to važno iz razloga što se u području istraživanja agresivnosti upravo nailazi na problem različitih definicija i konceptualizacija agresivnosti, pa se često kao dokaze povezanosti agresivnog ponašanja s različitim korelatima navode veze $\mathrm{s}$ delinkventnim ponašanjem, vršnjačkim nasiljem, eksternaliziranim poremećajima i sl., što može dovesti do pogrešnih zaključaka. 


\section{Emocionalna inteligencija i agresivnost u predškolskoj dobi}

U predškolskoj se dobi varijable emocionalne inteligencije $\mathrm{i}$ agresivnosti uglavnom ispituju opažanjem ponašanja, testovima prilagođenima dobi djece $i$ procjenama odgojitelja odnosno učitelja. Istraživanje koje su Arsenio, Cooperman i Lover (2000) proveli na predškolcima pokazalo je da je emocionalno znanje (dijete procjenjuje koje emocije doživljavaju likovi u situacijama prezentiranim pomoću lutaka) već u toj dobi povezano s agresivnošću opažanom u prirodnim uvjetima, a korelacija iznosi čak $r=-.50$. Emocionalno se znanje $\mathrm{u}$ istom istraživanju pokazalo i negativnim prediktorom agresivnosti, uz kontrolu varijabli emocionalnog doživljavanja različitih emocija (mjerenih također opažanjem u prirodnim uvjetima), između ostalih i ljutnje. Brebrić (2008) je na uzorku djece u jednoj hrvatskoj osnovnoj školi pri upisu u školu (6/7 godina) testovima ispitala sposobnost odgode zadovoljstva i prepoznavanja emocija, te četiri godine kasnije od učitelja prikupila procjene agresivnog ponašanja. Učenici koji su bili uspješniji u zadacima odgode zadovoljstva, ali ne i prepoznavanja emocija, imali su manje izraženo agresivno ponašanje. Razlog zbog kojeg prepoznavanje emocija nije ostvarilo povezanost $\mathrm{s}$ agresivnošću mogao bi biti prilično dug period između procjene tih dvaju konstrukata. Test odgode zadovoljstva je, unatoč dugom periodu između dviju procjena, ostvario povezanost s agresivnim ponašanjem, što može govoriti o važnosti uloge sposobnosti odgode zadovoljstva u razvoju agresivnosti. Schultz, Izard i Bear (2004) u svom su istraživanju na djeci 1. i 2. razreda osnovne škole dobili nešto drugačije rezultate. Kod njih je uspješnost u percepciji i dekodiranju emocionalnih signala $\mathrm{u}$ negativnoj korelaciji $\mathrm{s}$ učiteljskim procjenama agresivnosti, iako je ta korelacija prilično niska $(r=.16, p<.05)$. U istraživanju koje su proveli Underwood, Coie i Herbsman (1992), također na djeci školske dobi, pokazalo se da djeca koja su agresivnija prema procjenama vršnjaka rjeđe koriste pravila o pokazivanju ljutnje, a sva djeca češće upotrebljavaju ta pravila u prisutnosti nastavnika. Ovi rezultati upućuju na važnost učenja tih pravila, ali i poticanja djece da ih koriste u različitim kontekstima, što bi osobito moglo biti važno za djecu koja odrastaju u okolini u kojoj su pravila manje vidljiva i manje se koriste.

Opisana istraživanja pokazuju da varijable emocionalnih sposobnosti ostvaruju značajne povezanosti $\mathrm{s}$ varijablama agresivnosti u predškolskoj dobi. To je potvrđeno za tri razine sposobnosti EI (prepoznavanje, razumijevanje i upravljanje emocijama). Vrijednost je ovih rezultata $u$ tome što su u svim izloženim istraživanjima varijable EI i agresivnost mjerene različitim metodama, čime je mogućnost ostvarivanja značajne povezanosti na temelju primjene iste metode $u$ mjerenju dva konstrukta isključena. Osim toga, primijenjene metode često uključuju opažanje djece u realnim uvjetima, bilo trenutno ili odgođeno, što povećava vanjsku valjanost rezultata dobivenih ovim istraživanjima. 


\section{Emocionalna inteligencija i agresivnost kod starije djece $i$ adolescenata}

U studijama na starijoj djeci i adolescentima za mjerenje EI koriste se samoprocjene (za ukupnu EI), ali i testovi učinka (za pojedine emocionalne sposobnosti). S druge strane, agresivnost se mjeri samoprocjenama te vršnjačkim i učiteljskim procjenama. Istraživanje koje je provela Mohorić (2012) na uzorku djece petog razreda pokazalo je da sposobnost razumijevanja emocija mjerena testom učinka samostalno (uz kontrolu spola, dobi, opće inteligencije i osobina ličnosti) objašnjava 3.2\% varijance samoprocijenjenog agresivnog ponašanja. Grgić i sur. (2014) su na uzorku ranih adolescenata primijenile tri testa EI namijenjenih mjerenju sposobnosti prepoznavanja, razumijevanja i upravljanja emocija te ispitale mogućnost predikcije samoprocijenjene agresivnosti na temelju rezultata tih testova. Samo se Test upravljanja emocijama pokazao značajnim prediktorom agresivnog ponašanja i to kod dječaka. Ovi rezultati upućuju na potrebu uvođenja medijatorskih $\mathrm{i}$ moderatorskih varijabli $\mathrm{u}$ istraživanja povezanosti između emocionalnih sposobnosti i agresivnosti, ali i potencijalno drugačijih pristupa u interventne aktivnosti kod učenika različitih karakteristika. U Rubinovu (1999; prema Mayer, Caruso i Salovey, 2000) je istraživanju dobiveno da je ukupni rezultat adolescenata na testu EI(AMEIS) negativno povezan s vršnjačkim procjenama direktne, relacijske i kombinirane agresivnosti. Petrides, Sangareau, Furnham i Frederickson (2006) su kod učenika petih razreda dobili da je samoprocijenjena EI negativno povezana s vršnjačkim i nastavničkim procjenama agresivnog ponašanja. Istraživanje Liau i sur. (2003) na srednjoškolcima u Maleziji pokazalo je da EI mjerena samoprocjenama predviđa delinkvenciju i agresivnost sudionika. Istraživanje koje je provela Siu (2009) na hongkongškim adolescentima, također pomoću upitnika samoprocjene, pokazalo je da je loša upotreba emocija (2. razina) pozitivno povezana s agresivnim ponašanjem. U istraživanju koje su proveli Mavroveli, Petrides, Rieffe i Bakker (2007) pak nije dobivena povezanost između samoprocijenjene EI i vršnjačkih procjena agresivnosti adolescenata prosječne dobi od 14 godina.

Rezultati istraživanja na adolescentima uglavnom potvrđuju povezanost emocionalne inteligencije i agresivnosti, no ipak nisu jednoznačni. Nema dokaza da je sposobnost prepoznavanja emocija mjerena testom učinka samostalno povezana s agresivnošću u ovoj dobi, iako je očekivano da osobe koje točnije identificiraju emocije drugih ljudi na njih odgovaraju s manje agresivnih odgovora. Ta bi pretpostavka bila i u skladu s nalazima o teškoćama čitanja socijalnih znakova kod agresivnih pojedinaca (npr. Dodge, Lochman, Harnish, Bates i Pettit, 1997). Test namijenjen mjerenju sposobnosti razumijevanja emocija u jednom je istraživanju ostvario negativnu povezanost sa samoprocjenama agresivnosti (Mohorić, 2012), no u drugom se istraživanju ta veza nije pokazala značajnom (Grgić i sur., 2014). Jedino istraživanje koje je provjerilo vezu između sposobnosti upravljanja emocijama i agresivnosti tu vezu je i potvrdilo, ali samo za dječake (Grgić i sur., 2014). Ukupni je rezultat na testu EI u jednom istraživanju negativno povezan s različitim vrstama agresivnosti (Rubinovom, 1999; prema Mayer i sur., 2000). Samoprocijenjena se 
ukupna EI u nekoliko istraživanja pokazala negativno povezanom s različitim mjerama agresivnosti (Liau i sur., 2003; Siu, 2009), dok jedno istraživanje tu vezu nije potvrdilo (Mavroveli i sur., 2007).

Metode mjerenja primijenjene $\mathrm{u}$ ovim istraživanjima više su, $\mathrm{u}$ usporedbi $\mathrm{s}$ istraživanjima na predškolcima, ovisne o efektu procjenjivača, pa bi uvođenje metoda opažanja (osobito u realnim uvjetima), ali i studija koje bi usporedile različite metode, bilo korisno kako bi se mogla bolje procijeniti valjanost podataka.

\section{Osvrt na istraživanja povezanosti emocionalne inteligencije i agresivnosti}

Već sam broj navedenih istraživanja sugerira da je veza između EI i njezinih komponenata s agresivnošću nedovoljno istražena, unatoč važnosti i za validaciju konstrukta EI i za prevenciju agresivnog ponašanja. Istraživanja na mlađoj djeci, kao i razvojna istraživanja EI, temelje se više na konceptualizacijama izvan EI. S druge strane, istraživanja na starijim sudionicima u većoj mjeri proizlaze iz područja EI, no češće procjenjuju EI upitnicima samoprocjene, čije smo nedostatke (davanje socijalno poželjnih odgovora, pitanje u kojoj mjeri svaka osoba može objektivno procijeniti vlastite sposobnosti i osobine, blaži/stroži kriterij procjene) već spominjali u poglavlju vezanom uz razvoj i korelate agresivnosti. Čini se da kompleksnost modela i teškoće u mjerenju varijabli EI i ovdje predstavljaju prepreku za istraživače, slično kao u ispitivanjima razvoja o kojima smo govorili u poglavlju vezanom za osvrt na istraživanja razvoja emocionalnih sposobnosti. Uspoređujući različite razine EI, veza se između upravljanja emocijama i agresivnosti pokazala najstabilnijom, dok je veza prepoznavanja emocija s agresivnošću najmanje stabilna. To je u skladu s teorijskim pretpostavkama i drugim istraživanjima. Varijable prepoznavanja i inače ostvaruju niske ili nulte povezanosti s drugim kriterijskim varijablama (npr. Austin, 2010; MacCann, Fogarty, Zeidner i Roberts, 2011), a upravljanje emocija je teoretski, ali i prema rezultatima istraživanja, najviše povezano s funkcioniranjem u stvarnom životu (npr. Extremera i Fernández-Berrocal, 2006; O'Conner \& Little, 2003). Druga je razina modela Mayera i Saloveya (1997) i u ispitivanju ovog problema u potpunosti zanemarena, a potencijalni su razlozi opisani u dijelu koji se odnosi na osvrt na istraživanja razvoja emocionalnih sposobnosti. Mjere ukupne EI uglavnom su povezane s različitim mjerama agresivnosti, no uglavnom se radi o samoprocjenama.

Što se tiče agresivnosti, ona je u ovim istraživanjima uglavnom shvaćena kao jedinstveni konstrukt i mjerena kratkim upitničkim mjerama (osim u nekim istraživanjima na mlađim uzorcima). Ne nalazi se razlikovanje različitih tipova agresivnosti, a smatramo da bi to moglo biti važno, osobito u odnosu na direktnu i indirektnu agresivnost. Moglo bi se pretpostaviti da pojedinci s višim sposobnostima EI više primjenjuju indirektne nego direktne oblike agresivnih ponašanja. 


\section{Zaključak}

Sveukupno gledajući, dosadašnja su istraživanja potvrdila povezanost između mjera EI i agresivnosti, ali su spoznaje o tom problemu još uvijek nepotpune. Prije svega, istraživanja je malo, a većina ih uključuje samo neke aspekte EI mjerene samo nekom od metoda. S obzirom na to da većina metoda ima svoje nedostatke, potrebno je temeljitije metodološki osmisliti istraživanja tako da uključuju različite metode mjerenja i tako da se pokušaju umanjiti nedostaci onih metoda koje su primijenjene. Da bi se u potpunosti iskoristile mogućnosti koje bi nova istraživanja odnosa EI i agresivnosti donijela, treba jednako temeljito u istraživanjima pristupiti i odabiru mjera za procjene agresivnog ponašanja, s obzirom na to da su to ponašanja s niskom učestalošću javljanja koja je ponekad teško razlikovati od neagresivnih ponašanja. Svakako treba razlikovati direktna od indirektnih agresivnih ponašanja te ostale njihove podvrste (dio koji se odnosi na agresiju). Dakle, potrebne su nove studije koje bi uključile različite razine EI mjerene različitim metodama (samoprocjene, procjene bliskih ljudi, testovi učinka, opažanje), a isto tako i različite vrste agresivnih ponašanja zahvaćene također na različite načine. Istraživanja bi također trebala uključiti i sudionike različitih dobnih skupina te usporediti odnose među varijablama na tim dobnim skupinama. S obzirom na to da mnogi programi za prevenciju agresivnog ponašanja, kako je već spomenuto, nude različite aktivnosti čija je svrha poboljšanje emocionalnih sposobnosti, neophodno je pronaći znanstvene temelje za to. Zbog toga je važno u istraživanjima se usmjeriti na ispitivanje specifičnih veza između svake razine EI, užih sposobnosti koje pripadaju pojedinim razinama i različitih oblika agresivnosti, kao i na mogućnosti utjecaja na svaku od specifičnih sposobnosti s obzirom na njihove razvojne putanje i važnost za agresivno ponašanje u pojedinoj točki razvoja. Osim toga, bitno je odrediti i položaj varijabli EI unutar konstelacije mnogih drugih korelata agresivnog ponašanja u različitim razvojnim razdobljima. S obzirom na mnoga neodgovorena pitanja u ovom je području puno prostora za nova istraživanja.

\section{Literatura}

Alink, L.R., Mesman, J., van Zeijl, J., Stolk, M.N., Juffer, F., Koot, H.M., BakermansKranenburg, M.J. i van Ijzendoorn, M.H. (2006). The early childhood aggression curve: Development of physical aggression in 10- to 50-month-old children. Child Development, 77, 954-966.

Arsenio, W.F., Cooperman, S. i Lover, A. (2000). Affective predictors of preschoolers' aggression and peer acceptance: Direct and indirect effects. Developmental Psychology, $36(4), 438-448$.

Ashiabi, G.S. (2000). Promoting the emotional development of preschoolers. Early Childhood Education Journal, 2(2), 79-84. 
Austin, E.J. (2005). Emotional intelligence and emotional information processing. Personality and Individual Differences, 39, 403-414.

Bandura, A. (1973). Aggression: A social learning analysis. Englewood Cliffs. NJ: PrenliceHall.

Bandura, A., Ross, D. i Ross, S.A. (1961). Transmission of aggression through imitation of aggressive models. Journal of Abnormal and Social Psychology, 63, 575-582.

Barker, E.D., Boivin, M., Brendgen, M., Fontaine, N., Arseneault, L., Vitaro, F., Bissonnette, C. i Tremblay, R.E. (2008). Predictive validity and early predictors of peer-victimization trajectories in preschool. Archives of General Psychiatry, 65, 1185-1192.

Batool, S.S. (2013). Lack of adequate parenting: A potential risk factor for aggression among adolescents. Pakistan Journal of Psychological Research, 28(2), 217-238.

Beer, J.S., Knight, R.T. i D'Esposito, M. (2006). Controlling the integration of emotion and cognition: The role of frontal cortex in distinguishing helpful from hurtful emotional information. Psychological Science, 17(5), 448-453.

Björkqvist, K. i Österman, K. (1992). Parental influence on children's self-estimated aggressiveness. Aggressive Behavior, 18, 411-423.

Bohnert, A.M., Crnic, K.A. i Lim, K.G. (2003). Emotional competence and aggressive behavior in school-age children. Journal of Abnormal Child Psychology, 31(1), 79-91.

Bongers, I.L., Koot, H.M., van der Ende, J. i Verhulst, F.C. (2003). The normative development of child and adolescent problem behavior. Journal of Abnormal Psychology, 112(2), 179-192.

Boyatzis, C.J., Chazan, E. i Ting, C.Z. (1993). Preschoolers children's decoding of facial emotions. Journal of Genetic Psychology, 154, 375-382.

Brame, B., Nagin, D.S. i Tremblay, R.E. (2001). Developmental trajectories of physical aggression from school entry to late adolescence. Journal of Child Psychology and Psychiatry, 42(4), 503-512.

Brebić, Z. (2008). Neke komponente emocionalne inteligencije, školski uspjeh, prosocijalno i agresivno ponašanje učenika u primarnom obrazovanju. Napredak, 149(3), 296-311.

Bridges, L.J. i Grolnick, W.S. (1995). The development of emotional self-regulation in infancy and early childhood. U: N. Eisenberg (Ur.), Social development (str. 185-211). Thousand Oaks: Sage Publications.

Bronson, M.B. (2000). Self-regulation in early childhood: Nature and nurture. New York: Guilford Press.

Bruce, V., Campbell, R.N., Doherty- Sneddon, G., Import, A., Langton, S. i McAuley, S. (2000). Testing face processing skills in children. British Journal of Developmental Psychology, 18, 319-333.

Burnett, S., Thompson, S., Bird, G. i Blakemore, S.J. (2010). Pubertal development of the understanding of social emotions: Implications for education. Learning end Individual Differences, 21(6), 681-689. 
Cairns, R.B., Cairns, B.D., Neckerman, H.J., Ferguson, L.L. i Gariépy, J. (1989). Growth and aggression: Childhood to early adolescence. Developmental Psychology, 25(2), 320330.

Cakić, L. i Velki, T. (2014). Agresivnost i prihvaćenost u skupini djece predškolske dobi. Život $i$ škola, 32(2), 15-25.

Camras, L.A. i Allison, K. (1985). Childrens' understanding of emotional facial expressions and verbal labels. Journal of Nonverbal Behavior, 9, 84-94.

Card, N.A., Stucky, B.D., Sawalani, G.M. i Little, T.D. (2008). Direct and indirect aggression during childhood and adolescence: A meta-analytic review of gender differences, intercorrelations, and relations to maladjustment. Child Development, 79(5), 1185-1229.

Choie, J.D. i Dodge, K.A. (1997). Aggression and antisocial behavior. U: P. Mussen, W. Damon i N. Eisenberg (Ur.), Handbook of child psychology (5th ed.): Social, emotional and personality development (Vol. 3, str. 779-862). New York: Wiley.

Cole, P.M., Michel, M.K. i Teti, L.O. (1994). The development of emotion regulation and dysregulation: A clinical perspective. Monographs of the Society for Research in Child Development, 59(2-3), 73-100.

Crick, N.R., Casas, J.F. i Mosher, M. (1997). Relational and overt aggression in preschool. Developmental Psychology, 33(4), 579-588.

Crick, N.R., Werner, N.E., Casas, J.F., O'Brien, K.M., Nelson, D.A., Grotpeter, J.K. i Markon, K. (1999). Childhood aggression and gender: A new look at an old problem. U: D. Bernstein (Ur.), Gender and motivation (str. 75-141). Lincoln, NE: University of Nebraska Press.

Damar, M., Gülay, H. i Seven, S. (2011). Assessing the relationship between television programme choices and aggression tendencies in children going through early adolescence. International Journal of Academic Research, 3(4), 257-262.

Demetriou, A. (2000). Organization and development of self-understanding and selfregulation. U: M. Zeidner (Ur.), Handbook of self-regulation (str. 209-251). San Diego: CA: Academic.

Denham, S.A. (1998). Emotional development in young children. New York London: The Guilford Press.

Denham, S.A. i Couchoud, E.A. (1990). Young preschoolers' understanding of emotion. Child Study Journal, 20, 171-192.

Dennissen, J.J.A., Asendorpf, J.B. i van Aken, M.A.G. (2008). Trajectories of shyness and agressiveness in the context of demographic transitions in emerging adulthooh. Journal of Personality, 76(1), 67-99.

Dodge, K.A., Coie, J.D. i Lynam, D. (2007). Aggression and antisocial behavior in youth. U: W. Damon i R.M. Lerner (Ur.), Handbook of child psychology, Vol. 3: Social, emotional, and personality development (str. 719-788). New York: Wiley.

Dodge, K.A., Lochman, J.E., Harnish, J.D., Bates, J.E. i Pettit, G.S. (1997). Reactive and proactive aggression in school children and psychiatrically impaired chronically assaultive youth. Journal of Abnormal Psychology, 106, 37-51. 
Dunn, J., Brown, J.R. i Beardsall, L. (1991). Family talk about feeling states and children's later understanding of others'emotions. Developmental Psychology, 27, 448-455.

Durand, K., Gallay, M., Seigneuric, A., Robichon, F. i Baudouin, J. (2007). The development of facial emotion recognition: The role of configural information. Journal of Experimental Child Psychology, 97, 14-27.

Dutt, D., Pandey, G.K., Pal, D., Hazra, S. i Dey, T.K. (2013). Aggressive behaviour among school children in a rural area of West Bengal. Indian Journal of Community Medicine, 38(2), 109-113.

Đuranović, M. i Opić, S. (2013). Social aggression among pupils in primary school. Croatian Journal of Education, 15(3), 777-799.

Extremera, N. i Fernandez-Berrocal, P. (2006). Emotional intelligence as predictor of mental, social and physical health in university students. The Spanish Journal of Psychology, 9(1), 45-51.

Fan, H., Jackson, T., Yang, X., Tang, W. i Zhang, J. (2010). The factor structure of the MayerSalovey-Caruso Emotional Intelligece Test V 2.0 (MSCEIT): A meta-analytic structural equation modeling approach. Personality and Individual Differences, 48(7), 781-785.

Feldman, R. (2007). On the origins of background emotions: From affect synchrony to symbolic expression. Emotion, 7(3), 601-611.

Field, T.M. i Walden, T.A. (1982). Production and discrimination of facial expressions by preschool children. Child Development, 53, 1299-1311.

Gleason, K.A., Jensen-Campbell, L.A. i Richardson, D.S. (2004). Agreeableness as s predictor of aggression in adolescence. Aggressive Behavior, 30, 43-61.

Gosselin, P. (1995). Le dévelopment de la reconnaissance des expressions faciales des émotions chez l'enfant (The development of the recognition of facial expressions of emotion in children). Canadian Journal of Behavioral Sciences, 27, 107-119.

Grgić, N., Babić Čikeš, A. i Ručević, S. (2014). Sposobnosti emocionalne inteligencije kao prediktori prosocijalnog i agresivnog ponašanja učenika rane adolescentne dobi. Život $i$ škola: Časopis za teoriju i praksu odgoja i obrazovanja, 60(32), 43-60.

Grolnick, W.S., Bridges, L.J. i Connell, J.P. (1996). Emotion regulation in two year olds: Strategies and emotional expression in four contexts. Child Development, 67, 928-941.

Grossmann, T. (2010). The development of emotion perception in face and voice during infancy. Restorative Neurology and Neuroscience, 28, 219-236.

Gullone, E., Hughes, E., Neville, J. i Tonge, B. (2010). The normative development of emotion regulation strategy use in children and adolescents: A 2-year follow-up study. Journal of Child Psychology and Psychiatry, 51, 567-574.

Hartup, W.W. (1974). Aggression in childhood: Developmental perspectives. American Psychologist, 29, 336-341.

Herba, C.M., Landau, S., Russell, T., Ecker, C. i Phillips, M.L. (2006). The development of emotion-processing in children: Effects of age, emotion, and intensity. Journal of Child Psychology and Psychiatry, 47(11), 1098-1106. 
Horton, P. (2011). School bullying and social and moral orders. Children \& Society, 25, 268277.

Hubbard, J.A., McAuliffe, M.D., Morrow, M.T. i Romano, L.J. (2010). Reactive and proactive aggression in childhood and adolescence: Precursosr, outcomes, processes, experiences, and measurement. Journal of Personality, 78(1), 95-118.

Jaffe, M., Gullone E. i Hughes, E.K. (2010). The roles of temperamental dispositions and perceived parenting behaviours in the use of two emotion regulation strategies in late childhood. Journal of Applied Developmental Psychology, 31, 47-59.

Johnson, K.J., Waugh, C.E. i Fredrickson, B.L. (2010). Smile to see the forest: Facially expressed positive emotions broaden cognition. Cognition and Emotion, 24(2), 299321.

Keresteš, G. (2002). Dječje agresivno i prosocijalno ponašanje u kontekstu rata. Jastrebarsko: Naklada Slap.

Keresteš, G. (2006). Mjerenje agresivnoga i prosocijalnoga ponašanja školske djece: Usporedba procjena različitih procjenjivača. Društvena istraživanja, 1-2(81-82), 241264.

Kokko, K., Pulkkinen, L., Huesmann, L.R., Dubow, E.F. i Boxer, P. (2009). Intensity of aggression in childhood as a predictor of different forms of adult aggression: $\mathrm{S}$ twocountry (Finland and the United States) analysis. Journal of Research on Adolescence, 19(1), 9-34.

Kopp, C. (1989). Regulation of distress and negative emotions: A developmental view. Developmental Psychology, 25(3), 343-354.

Lee, K.H., Baillargeon, R.H., Vermunt, J.K., Wu, H.X. i Tremblay, R.E. (2007). Age differences in the prevalence of physical aggression among 5-11-year-old Canadian boys and girls. Aggressive Behavior, 33, 26-37.

Levine, L.J. i Edelstein, R.S. (2009). Emotion and memory narrowing: A review and goalrelevance approach. Cognition and Emotion, 23(5), 833-875.

Lewis, M., Sullivan, M. i Vasen, A. (1987). Making faces: Age and emotion differences in the posing of emotional expressions. Developmental Psychology, 23, 690-697.

Liau, A.K., Liau, A.W., Teoh, G.B.S. i Liau, M.T.L. (2003). The case for emotional literacy: The influence of emotional intelligence on problem behaviours in Malaysian secondary school students. Journal of Moral Education, 32(1), 51-66.

Little, T.D., Jones, S.M., Henrich, C.C. i Hawley, P.H. (2003). Disentangling the "whys" from "whats" of aggressive behavior. International Journal of Behavioral Development, 27, 122-133.

MacCann, C., Fogarty, G.J., Zeidner, M. i Roberts, R.D. (2011). Coping mediates the relationship between emotional intelligence (EI) and academic achievement. Contemporary Educational Psychology, 36, 60-70.

Malatesta, C.Z., Culver, C., Tesman, J.R. i Shepard, B. (1989). The development of emotional expression during the first two years of life. Monographs of the Society for Research in Child Development, 54(1-2), 105-136. 
Mangelsdorf, S.C., Shapiro, J. i Marzolf, D. (1995). Developmental and temperamental differences in emotion regulation in infancy. Child Development, 66, 1817-1828.

Mathersul, D., Palmer, D.M., Gur, R.C., Gur., R.E., Cooper, N., Gordon, E. i Williams, L.M. (2009). Explicit identification and implicit recognition of facial emotions: II. Core domains and relationships with general cognition. Journal of Clinical and Experimental Neuropsychology, 31(3), 278-291.

Mavroveli, S., Petrides, K.V., Rieffe, C. i Bakker, F. (2007). Trait emotional intelligence, psychological well-being and peer-rated social competence in adolescence. British Journal of Developmental Psychology, 25, 263-275.

Mayer, J.D., Caruso, D.R. i Salovey, P. (2000). Selecting a measure of emotional intelligence: The case for ability scales. U: R. Bar-On i J.D. Parker (Ur.), Handbook of emotional intelligence (str. 320-340). New York: Jossey Bass.

Mayer, J.D. i Salovey, P. (1997). What is emotional intelligence?. U: P. Salovey i D. Sluyter (Ur.), Emotional development and emotional intelligence: Implications for educators (str. 3-31). New York: Basic Books.

Mayer, J.D., Salovey, P., Caruso, D.R. i Sitarenios, G. (2003). Measuring emotional intelligence with the MSCEIT V2.0. Emotion, 3, 97-105.

McCabe, A. i Lopscomb, T.T. (1988). Seks differences in children's verbal aggresion. MerrillPalmer Quarterly, 34, 389-401.

McIntyre, H.H. (2010). Gender differences in the nature and linkage of higher-order personality factors to trait and ability emotional intelligence. Personality and Individual Differences, 48, 617-622.

McLaughlin, K.A., Hatzenbuehler, M.L., Mennin, D.S. i Nolen-Hoeksema, S. (2011). Emotion dysregulation and adolescent psychopathology: A prospective study. Behaviour Research and Therapy, 49, 544-554.

McRae, K., Gross, J.J., Weber, J., Robertson, E.R., Sokol-Hessner, P., Ray, R.D., Gabrieli, J.D.E. i Ochsner, K.N. (2012). The development of emotion regulation: An fMRI study of cognitive reappraisal in children, adolescents and young adults. SCAN, 7, 11-22.

Mohorić, T. (2012). Razumijevanje emocija kao komponenta emocionalne inteligencije u ranoj adolescenciji. (Neobjavljena doktorska disertacija). Sveučilište u Zagrebu, Filozofski fakultet, Zagreb.

Munjas, R. (2007). Utjecaj emocionalnog opismenjavanja na razvoj emocionalne kompetentnosti u ranoj adolescenciji. (Neobjavljena magistarska radnja). Sveučilište u Zagrebu, Filozofski fakultet, Zagreb.

Murphy, B., Eisenberg, N., Fabes, R.A., Shepard, S. i Guthrie, I.K. (1999). Consistency and change in children's emotionality and regulation: A longitudinal study. Marrill-Palmer Quarterly, 45, 413-444.

O'Connor, R.M. i Little, I.S. (2003). Revisiting the predictive validity of emotional intelligence: Self-report versus ability-based measures. Personality and Individual Differences, 35, 1893-1902. 
Ojanen, T., Findley, D. i Fuller, S. (2012). Physical and relational aggression in early adolescence: Associations with narcissism, temperament, and social goals. Aggressive Behavior, 38, 99-107.

Parke, R.D. i Slaby, R.G. (1983). The development of aggression. U: P.H. Mussen i E.M. Hetherington (Ur.), Handbook of child psychology, Vol. 4: Socialization, personality, and social development (str. 547-642). New York: Wiley.

Pei, M. (2011). The relation between parent-child attachment, child-rearing behaviors, and aggression in childhood and adolescence. (Neobjavljena magistarska radnja). Brandeis University, Department of Psychology, Waltham.

Perron, M., Gosselin, P., Gagnon, M., Beaupré, M., Jomphe, M. i Doucet, M. (2009). The understanding of emotion dissimulation in school-aged children. Advances in Psychology Research, 59, 1-16.

Pérusse, D. i Gendreau, P.L. (2005). Genetics and the development of aggression. U: R. Tremblay, W.W. Hartup i J. Archer (Ur.), Developmental origins of aggression (str. 223-241). New York: Guilford.

Petrides, K.V., Furnham, A. i Mavroveli, S. (2007). Trait emotional intelligence: Moving forward in the field of EI. U: G. Matthews, M. Zeidner i R. Roberts (Ur.), Emotional intelligence: Knowns and unknowns (Series in affective science) (str. 151-166). Oxford: Oxford University Press.

Petrides, K.V., Sangareau, Y., Furnham, A. i Frederickson, N. (2006). Trait emotional intelligence and children's peer relations at school. Social Development, 15, 537-547.

Raffaeli, M., Crockett, L.J. i Shen, Y. (2005). Developmental stability and change in selfregulation from childhood to adolescence. The Journal of Genetic Psychology, 166(1), 54-75.

Ridgeway, D., Waters, E. i Kuczaj, S.A. (1985). Acquisition of emotion-descriptive language: Receptive and productive vocabulary norms for ages 18 months to 6 years. Developmental Psychology, 21, 901-908.

Roberts, R.D., Zeidner, M. i Matthews, G. (2001). Does emotional intelligence meet traditional standards for an intelligence? Some new data and conclusions. Emotion, 1(3), 196-231.

Russell, J.A. (1990). The preschooler's understanding of the causes and consequences of emotion. Child Development, 61, 1872-1881.

Ružić, N. (2011). Internet i videoigre: Uzročnici povećane agresivnosti među mladima. Medijske studije, 2(3-4), 16-27.

Saarni, C. (2000). Emotional competence: A developmental perspective. U: R. Bar-On i J.D.A. Parker (Ur.), The handbook of emotional intelligence: Theory, development, assessment, and application at home, school, and in the workplace (str. 68-91). San Francisco, CA: Jossey-Bass.

Silk, J.S., Steinberg, L. i Morris, A.S. (2003). Adolescents' emotion regulation in daily life: Links to depressive symptoms and problem behavior. Child Development, 74, 18691880 . 
Siu, A.F. (2009). Trait emotional intelligence and its relationships with problem behavior in Hong Kong adolescents. Personality and Individual Differences, 47, 553-557.

Sheffield Morris, A., Silk, J.S., Steinberg, L., Myers, S.S. i Robinson, L.R. (2007). The role of the family context in the development of emotion regulation. Social Development, 16(2), 361-388.

Schultz, D., Izard, C.E. i Bear, G. (2004). Children's emotion processing: Relations to emotionality and aggression. Development and Psychopathology, 16, 371-387.

Smith, R.L., Rose, A.J. i Schwartz-Mette, R.A. (2010). Relational and overt aggression in childhood and adolescence: Clarifying mean-level gender differences and associations with peer acceptance. Social Development, 19(2), 243-269.

Storbeck, J. i Clore, G.L. (2007). On the interdependence of cognition and emotion. Cognition and Emotion, 21(6), 1212-1237.

Takšić, V., Mohorić, T. i Munjas, R. (2006). Emocionalna inteligencija: Teorija, operacionalizacija, primjena i povezanost s pozitivnom psihologijom. Društvena istraživanja, 4-5(84-85), 729-752.

Tapper, K. i Boulton, M.J. (2004). Seks differences in levels of physical, verbal, and indirect aggression amongst primary school children and their associations with beliefs about aggression. Aggressive Behavior, 30, 123-145.

TenHouten, W.D. (2012). Emotion and reason: Mind, brain, and the social domains of work and love. NY: Routledge.

Tremblay, R.E. (2000). The development of aggressive behaviour during childhood: What have we learned in the past century?. International Journal of Behavioral Development, 24(2), 129-141.

Tremblay, R.E., Japel, C., Pe'russe, D., Boivin, M., Zoccolillo, M., Montplaisir, J. i McDuff, P. (1999). The search for the age of "onset" of physical aggression: Rousseau and Bandura revisited. Criminal Behavior and Mental Health, 9, 8-23.

Ujedinjeni narodi (1948). Opća deklaracija o pravima čovjeka. Preuzeto s http://www.ohchr.org/EN/UDHR/Documents/UDHR_Translations/src2.pdf

Underwood, M.K., Coie, J.D. i Herbsman, C.R. (1992). Display rules for anger and aggression in school-age children. Child Development, 63, 366-380.

Ustavni sud Republike Hrvatske (2011). Ustav Republike Hrvatske (pročišćeni tekst). Preuzeto s http://www.usud.hr/uploads/Redakcijski\%20prociscen\%20tekst\% 20Ustava \%20Republike\%20Hrvatske,\%20Ustavni\%20sud\%20Republike\%20Hrvatske,\%2023. \%20ozujka\%202011.pdf

Wahl, K. i Metzner, C. (2012). Parental influences on the prevalence and development of child aggressiveness. Journal of Child and Family Studies, 21, 344-355.

Wang, Y., Liu, H. i Su, Y. (2014). Development of preschoolers' emotion and false belief understanding: A longitudinal study. Social Behavior and Personality, 42(4), 645-654.

Widen, S.C. i Russell, J.A. (2008). Children acquire emotion categories gradually. Cognitive Development, 23, 291-312. 
Williams, C., Daley, D., Burnside, E. i Hammond-Rowley, S. (2010). Can trait emotional intelligence and objective measures of emotional ability predict psychopathology across transition to secondary school?. Personality and Individual Differences, 48, 161-165.

Zeman, J. i Shipman, K. (1997). Social-contextual influences on expectancies for managing anger and sadness: The transition from middle childhood to adolescence. Developmental Psychology, 33, 917-924.

Zimmermann, P. i Iwanski, A. (2014). Emotion regulation from early adolescence to emerging adulthood and middle adulthood: Age differences, gender differences, and emotion-specific developmental variations. International Journal of Behavioral Development, 38(2), 182-194.

Xie, H., Drabick, D.A.G. i Chen, D. (2011). Developmental trajectories of aggression from late childhood through adolescence: Similarities and differences across gender. Aggressive Behavior, 37, 387-404.

\title{
Emotional Intelligence and Aggressive Behaviour in Childhood and Adolescence-An Overview of Studies
}

\begin{abstract}
The purpose of this work was to review research about the development of emotional intelligence (EI) and aggressiveness during childhood and adolescence as well as to review studies that looked into the relationship between these constructs during that life frame. The review of the literature points to a possible association between developmental paths of emotional intelligence and aggression, although the research on the relationship between emotional experience and emotion processing variables with different aspects of aggressiveness are quite rare. The majority of existing research indicates a significant correlation between these two constructs, but differences in conceptualizations, applied measures, patterns and methods, make it difficult to draw clear conclusions. The future research needs to be focused on the investigation of relationships between individual levels of EI, narrow abilities associated with it, and different forms of aggression. In addition, it is important to examine the possibility to influence each EI capability bearing in mind its developmental paths and its importance for aggressive behaviour at a particular point of development. The position of EI variables within the constellation of various correlates of aggressive behaviour at different points of development is also an important task of future research. The results of such studies would increase the efficiency of violence prevention programs, and allow for better assessment of the effectiveness of treatments for aggression.
\end{abstract}

Keywords: aggressiveness, emotional intelligence, childhood, adolescence 


\section{Inteligencia emocional y conducta agresiva en la niñez y adolescencia - revisión de investigaciones}

\section{Resumen}

El objetivo de este trabajo es ofrecer una revisión de investigaciones hechas sobre el desarrollo de la inteligencia emocional (IE) y la agresividad en la niñez y adolescencia, tanto como de los estudios que han tratado el tema de la relación entre estos dos constructos a esa edad. Ya la mera revisión de datos sobre el desarrollo indica posibles conexiones en los caminos de desarrollo de las capacidades emocionales y la agresividad. Pero, las investigaciones sobre la conexión entre las variables de la experiencia emocional y el procesamiento de las emociones con diferentes aspectos de la agresividad son bastante raras. La mayoría de los resultados existentes indicar la conexión entre estos dos constructos, pero el problema que impide llegar a las conclusiones claras está causado por las grandes diferencias en las conceptualizaciones, mediadas implementadas, muestras y métodos. En las futuras investigaciones es importante enfocarse en la investigación de enlaces específicos entre cada uno de los niveles de IE, capacidades relacionadas con ellos y diferentes formas de agresividad. Además, es importante examinar las posibilidades de influir en cada una de las capacidades específicas dependiendo de su camino de desarrollo, tanto como su importancia en cuanto a la conducta agresiva en cada uno de los puntos de desarrollo. La posición de las variables de IE dentro de la constelación de muchos otros correlatos de la conducta agresiva en diferentes etapas de desarrollo también figura como problema importante de posibles investigaciones. Aplicar los resultados de ese tipo de investigaciones para crear un programa de prevención de la conducta agresiva aumentaría su efectividad, pero también posibilitaría una valuación más válida del efecto de los tratamientos aplicados.

Palabras claves: agresividad, inteligencia emocional, niñez, adolescencia

Primljeno: 07.12.2015. 